\title{
COVID-19, children and anxiety in 2020
}

Jenni Parsons

FOR OUR CHILDREN, the 2020 world must seem a very frightening place indeed. After having spent the summer either experiencing directly, or seeing relentless images on television of, devastating bushfires, their world has now been turned upside down by an invisible adversary that makes interacting with others a potential threat. Their caregivers are anxious and stressed, not only about the virus itself but also about short- and long-term financial security. Children have been physically separated from their peers, teachers, grandparents, neighbours and communities.

These are extraordinary and uncertain times. It is normal to be worried. Almost all people exposed either directly or vicariously to a natural disaster or community-wide traumatic event will experience psychological distress. ${ }^{1}$ The child's psychological response is determined by their cognitive developmental level and understanding of the cause of the disaster, the reactions of family members, and the child's personality and coping mechanisms (their resilience). ${ }^{1}$ Preschool children may have sleep and appetite disturbances, be clingy or have separation anxiety, fear the dark or have nightmares, display regressive behaviours or have behaviour change. Importantly, young children do not recognise the existence of chance events and may attribute the disaster to something they have done. Children under three years of age are unlikely to be able to express their feelings verbally and are more likely to express their anxiety in drawings or in play. School-aged children may be more disorganised, exhibit disruptive behaviours, have increased arousal and hypervigilance, experience somatic symptoms or have decreased academic performance. As children move through adolescence, their symptoms approximate those of adults, and they may experience anxiety, lowered mood, guilt, anger, disillusionment and fears of a limited future. As a result, they may favour short-term pleasures over their studies and indulge in risk-taking behaviours or substance abuse. ${ }^{1}$

For the majority of children, these acute distress symptoms will not progress to a chronic stress response or a more serious condition such as acute stress disorder or post-traumatic stress disorder. Individual resilience factors in children include cognitive skills, empathy and a positive outlook. Resilience has also been shown to be enhanced by good relationships with caregivers, positive parenting approaches, social support from friends or adults, positive relationships with teachers, academic engagement, community cohesion and links with cultural identity. ${ }^{2}$ However, ongoing chronic stressors that continue to affect the family increase the risk of psychological symptoms and disorders. ${ }^{1,3}$ The ongoing economic and social impacts of the COVID-19 pandemic - such as unemployment, persisting school closures and other social restrictions, and an increased risk of domestic violence are likely to produce significant ongoing stresses to children and families. ${ }^{4}$ For children living in rural areas whose families are already under stress from bushfires or drought, COVID-19related socioeconomic stresses will be compounded. Children and adolescents with pre-existing mental health disorders are more likely to have more significant symptoms of anxiety during a pandemic.
According to The mental health of children and adolescents report in 2015, the prevalence of anxiety disorders in children and adolescents in Australia is 6.9\%. ${ }^{5}$ The prevalence was higher in those living in families with lower levels of income, lower parental education, parents not in employment or poor family functioning; those in single-parent families; and those living outside capital cities. These social determinants of health will be even more important in 2020, as these cohorts that will be disproportionally affected by the socioeconomic impacts of the COVID-19 pandemic. It is important that general practitioners (GPs) are alert to mental health disorders in children with these and other risks (Box 1).

The most important factors for maintaining and improving a child's socio-emotional wellbeing are parental mental wellbeing, consistent positive parenting and low levels of hostile parenting. ${ }^{6}$ Parents can minimise the negative psychological impacts for their children by: ${ }^{7,8}$

- looking after their own mental wellbeing

- providing clear, age-appropriate information

- reassuring their children that they are at low risk and that there is a plan to manage the overall risks of the virus

- reducing exposure to news and social media reporting related to COVID-19

- maintaining routines

- assisting children and adolescents to maintain social contacts via internetbased means

- involving children in a family plan to mitigate risk and promote positive mental and social wellbeing. For children and teenagers with (or at increased risk of developing) persistent 
or pervasive anxiety, a vital consideration for GPs is managing the mental health of parents and caregivers. We have an important role in educating and supporting parents to be able to mitigate

\section{Box 1. Risk factors for ongoing anxiety} disorders

- Socioeconomic disadvantage

- Pre-existing mental health issues in parent or child

- Living in regional or rural areas, particularly regions affected by recent bushfires or drought

- Domestic violence and manage these symptoms and instituting a stepped management plan. This may involve using age-appropriate evidence-based e-mental health resources and programs. Computer-based cognitive behavioural therapy programs have been shown to be an effective mode of delivery in meta-analyses, specifically for children with anxiety. ${ }^{9-11}$ It is important for GPs to familiarise themselves with what is available on the e-mental health sites they recommend. Some resources and programs lend themselves to practitioner supervision or support as the child works through the program (Table 1). The next level of care would be referring to psychological and psychiatric services such as those provided through Primary Health Networks, headspace and Child and Adolescent Mental Health Services (CAMHS), bearing in mind that access to face-to-face services may be limited. Private psychologists, mental health social workers and psychiatrists are also an appropriate referral option, but cost and availability can be problematic for many families.

First published online 19 June 2020.

\section{Author}

Jenni Parsons MBBS, DRANZCOG, FRACGP

General Practitioner, Port Fairy Medical Clinic, Vic. jenni_parsons@bigpond.com

Competing interests: None.

Table 1. Online mental health resources for children and teenagers

\begin{tabular}{|c|c|c|}
\hline Resource & Description & Website \\
\hline Kids Helpline & $\begin{array}{l}\text { Age-appropriate information for young children, teenagers and } \\
\text { young adults (including information about managing anxiety } \\
\text { related to news information), phone counselling, email and SMS } \\
\text { services. }\end{array}$ & https://kidshelpline.com.au \\
\hline Smiling Mind app & $\begin{array}{l}\text { Free app with short mindfulness exercises for children, } \\
\text { teenagers and adults that parents and children can practise } \\
\text { together easily. 'Thriving Inside' is a dedicated section of the } \\
\text { Smiling Mind website and Instagram account that is related } \\
\text { to managing COVID-19-related stress and maintaining } \\
\text { connectedness. }\end{array}$ & www.smilingmind.com.au/smiling-mind-app \\
\hline BITE BACK & $\begin{array}{l}\text { An online program from the Black Dog Institute for adolescents } \\
\text { aged 13-18 years based on positive psychology. It provides } \\
\text { information, a mental health fitness challenge and activities } \\
\text { such as 'THINK TANK' (a gratitude diary) and 'SNAP THAT' } \\
\text { (a mindfulness activity disguised as a photography activity). } \\
\text { The site focuses on developing and maintaining good mental } \\
\text { health practices. }\end{array}$ & www.biteback.org.au \\
\hline eheadspace & $\begin{array}{l}\text { Free online support and counselling for young people aged } \\
12-25 \text { years. Although it is not an emergency service, the site } \\
\text { does provide the option of one-on-one live chats from } 9.00 \mathrm{am} \\
\text { to } 1.00 \mathrm{pm} \text {, as well as moderated group chats and excellent } \\
\text { information for adolescents and families and friends. This site is } \\
\text { useful for those wanting information, for tools addressing mild } \\
\text { symptoms and for additional support between consultations. }\end{array}$ & https://headspace.org.au/eheadspace \\
\hline $\begin{array}{l}\text { headspace clinical } \\
\text { toolkit }\end{array}$ & Clinician guidelines for mental health disorders. & $\begin{array}{l}\text { https://headspace.org.au/health- } \\
\text { professionals/clinical-toolkit }\end{array}$ \\
\hline BRAVE-Online & $\begin{array}{l}\text { An evidence-based cognitive behavioural therapy-based online } \\
\text { program developed by The University of Queensland for children } \\
\text { and teenagers with anxiety symptoms. It has a parallel program } \\
\text { for parents to help them understand and manage what is } \\
\text { occurring for their children. It can be undertaken independently } \\
\text { by children and parents or has the option for assistance from an } \\
\text { online therapist. }\end{array}$ & www.brave-online.com \\
\hline
\end{tabular}


Provenance and peer review: Commissioned, peer reviewed.

Citation: Parsons J. COVID-19, kids and anxiety in 2020. Aust J Gen Pract 2020;49 Suppl 27. doi: 10.31128/AJGP-COVID-27.

\section{References}

1. Shaw JA, Espinel Z, Shultz, JM. Children: Stress, trauma and disaster. Tampa, FL: Disaster Life Support Publishing, 2007.

2. Gartland D, Riggs E, Muyeen S, et al. What factors are associated with resilient outcomes in children exposed to social adversity? A systematic review. BMJ Open 2019;9(4):e024870. doi: 10.1136/ bmjopen-2018-024870.

3. Bahn GH. Coronavirus disease 2019, school closures and children's mental health. J Korean Acad Child Adolesc Psychiatry 2020;31(2):74-79. doi: 10.5765/jkacap.200010.

4. Peterman A, Potts A, O'Donnell M, et al. Pandemics and violence against women and children. CGD Working Paper 528. Washington, DC: Center for Global Development, 2020.

5. Lawrence D, Johnson S, Hafekost J, et al. The mental health of children and adolescents. Report on the second Australian Child and Adolescent Survey of Mental Health and Wellbeing. Canberra, ACT: DoH, 2015.

6. Rioseco P, WarrenD, Daraganova G. Children's social-emotional wellbeing. The role of parenting, parents' mental health and health behaviours. Southbank, Vic: Australian Institute of Family Studies, 2020.

7. Goldschmidt K. The COVID-19 pandemic: Technology use to support the wellbeing of children. J Pediatr Nurs 2020. doi: 10.1016/j. pedn.2020.04.013. [Epub ahead of print]

8. National Workforce Centre for Child Mental Health. Supporting children during the Coronavirus (COVID-19) pandemic. North Adelaide, SA: Emerging Minds, 2020.

9. Andrews G, Basu A, Cuijpers P, et al Computer therapy for the anxiety and depression disorders is effective, acceptable and practical health care: An updated meta-analysis. J Anxiety Disord 2018;55:70-78. doi: 10.1016/j.janxdis.2018.01.001.

10. Montgomery P, Bjornstad GJ, Dennis JA. Mediabased behavioural treatments for behavioural problems in children. Cochrane Database Syst Rev 2006;(1):CD002206. doi: 10.1002/14651858. CD002206.

11. Vigerland $S$, Ljótsson $B$, Thulin U, Öst LG, Andersson G, Serlachius E. Internet delivered cognitive behavioural therapy for children with anxiety disorders: A randomised controlled trial. Behav Res Ther 2016;76:47-56. doi: 10.1016/j. brat.2015.11.006. 